УДК 281.93

ДЗЮБАН Валерий Валерьевич - доктор исторических наук, кандидат педагогических наук; профессор департамента социологии, истории и философии Финансового университета при Правительстве РФ (125993, Россия, г. Москва, Ленинградский пр-кт, 49; bryanskstudzuban@mail. ru)

КОЧЕРГИНА Марина Викторовна - кандидат исторических наук, доцент Московского финансово-юридического университета (МФЮА) (115191, Россия, г. Москва, ул. Серпуховский Вал, 17, кopn. 1; kochergina_mv@mail.ru)

\title{
СОПРОТИВЛЕНИЕ СТАРООБРЯДЦЕВ СТАРОДУБЬЯ И ВЕТКИ НАСИЛЬСТВЕННОМУ ИЗМЕНЕНИЮ ОРГАНАМИ СОВЕТСКОЙ ВЛАСТИ ТРАДИЦИОННОГО КУЛЬТУРНО- БЫТОВОГО УКЛАДА НАСЕЛЕНИЯ (1920-1930 гг.)
}

\begin{abstract}
Аннотация. Статья посвящена актуальной проблеме сохранения традиционного культурно-бытового уклада русскими старообрядцами древних духовных центров Стародубья и Ветки в период 19201930 гг., несмотря на идеологическое воздействие и репрессии со стороны органов советской власти. Этой проблеме уделяют внимание исследователи в других регионах компактного проживания старообрядцев, например на территории Урала, Сибири, стран Восточной Европы. Тема, разработанная авторами, ранее не исследовалась ни отечественными, ни зарубежными учеными.

Ключевые слова: старообрядцы, Стародубье, Ветка, коллективизация, индустриализация, духовные центры, идеологическое воздействие, репрессии
\end{abstract}

A ктуальность данной темы не вызывает сомнения. На основе изучения большой группы источников, найденных в период проведения архивных и полевых исследований, авторы ставят задачу всестороннего показа процесса неприятия старообрядцами насильственного изменения их традиционного культурно-бытового уклада со стороны органов советской власти на территории древних центров старообрядчества - Стародубья и Ветки - в указанный период. Источниками для написания данной статьи являются документы Государственного архива Гомельской области, Государственного архива общественных объединений Гомельской области, опубликованные в сборнике «Старообрядцы на Гомельщине», документы из государственных архивов Брянской и Смоленской обл., опубликованные в сборнике «История индустриализации Западного района (1926-1937 гг.). Документы и материалы»1. Большое число фотодокументов, воспоминаний представлены авторам членами старообрядческих общин Стародубского, Новозыбковского, Клинцовского районов Брянской обл.; неопубликованные документы извлечены нами из фондов Государственного архива Брянской области.

Старообрядческие поселения возникли на территории Стародубья и Ветки в последней четверти XVII - начале XVIII в. В XIX в. эти территории входили в состав северных уездов Черниговской и Могилевской губерний Российской

\footnotetext{
${ }^{1}$ Старообрядиы на Гомельщине (1918-1991): документы и материалы (сост. З.А. Александрович [и др.]; под ред. П.В. Пичукова). 2017. Минск. 412 с.; История индустриализации Западного района (1926-1937 г2.): документы и материалы (под ред. В.А. Смирнова, М.С. Кузнецовой, И.И. Фишмана, И.Е. Яненко, А.А. Черняева). 1972. Брянск. 614 с.
} 
империи. Согласно официальным источникам, общая численность старообрядческого населения Стародубья в 1914 г. составляла 75534 чел. обоего пола. В Гомельском уезде Могилевской губернии, где находились старообрядческие поселения древнего старообрядческого центра Ветки, среди религиозных конфессий второй по численности было старообрядчество - 17315 чел. Оно уступало по численности лишь представителям официального православия - 219795 чел. [Кочергина 2011]. На территории Стародубья население проживало в посадах и городах - это г. Новозыбков, посады Клинцы, Ардонь, Злынка, Свяцк, Деменка, Тимошкин Перевоз, Шеломы, Климов, Митьковка, Елионка, Воронок, Лужки, Радуль, Добрянка. Члены старообрядческих общин занимались промышленным предпринимательством, промыслами, торговлей, частично земледелием, т.к. земли были малоплодородными. Старообрядцы основали на территории Стародубья суконное и спичечное производство. Стремительный рост этих отраслей и их промышленное перевооружение произошло во второй половине XIX - начале XX в. ${ }^{1}$ Крупного промышленного производства на территории Ветки не было. Старообрядческое население проживало в городах, местечках и слободах - это слободы Косицкая, Марьина, Миличи, Грабовка, Нивки, Папсуевка, Огородня, Крупец, Леонтьева, Дубовый Лог, Тарасовка, Спасовка, Красная, местечко Ветка, г. Гомель. Деловая хватка старообрядцев реализовывалась в торговой деятельности и земледелии.

В период Первой русской революции 1905-1907 гг. на основе указа «Об укреплении начал веротерпимости» (17 апреля 1905 г.), подписанного императором Николаем II, и указа сенату «О порядке образования и действия старообрядческих и сектантских общин и о правах и обязанностях входящих в состав общин последователей старообрядческих согласий и отделившихся от православия сектантов» (17 октября 1906 г.) старообрядческие общины получили права юридических лиц и были уравнены в правах со всеми «инославными» конфессиями, кроме права публично пропагандировать свою веру [Фирсов 2002]. 1905-1917 гг. вошли в историю старообрядчества как «золотой век». На территории Стародубья и Ветки происходила регистрация старообрядческих общин, строительство храмов, возрождение старообрядческих монастырей. Старообрядцы активно участвовали в Февральской революции 1917 г., подготовили свою программу действий, не примыкая ни к леворадикальным, ни к правым партиям. Однако события октября 1917 г. старообрядцы не приняли. В период иностранной интервенции (1918-1919 гг.) территории этих старообрядческих духовных центров оказались оккупированными австро-германскими войсками по условиям сепаратного Брестского мира, заключенного Советской Россией с Германией в марте 1918 г. Окончательное изгнание интервентов с этой территории произошло в 1919 г. В период Гражданской войны произошло разрушение суконного и спичечного производства, были нарушены торговоэкономические связи старообрядцев-предпринимателей. Согласно декрету Совета народных комиссаров от 27 января 1918 г. «О порядке изменения границ губернских, уездных и проч.», подписанного В.И. Лениным², местные советы самостоятельно решали территориальные вопросы. В связи с этим произошло изменение административно-территориального деления. Бывшие территории северных уездов Черниговской губернии и сопредельных территорий Могилевской губернии - старообрядческие поселения Стародубья и Ветки вошли в состав Гомельской (1923 г.) и Брянской губерний (1926-1928 гг.). В этот

\footnotetext{
1 Там же.

2 Декрет СНК РСФСР от 27 января 1918 г. «О порядке изменения границ губернских, уездных и проч.» Доступ: http://istmat.info/node/28648 (проверено 20.01.2020).
} 
период были воссозданы органы советской власти, начались изменения в социальной структуре общества. Стойкое сопротивление старообрядцев изменению традиционного культурно-бытового уклада началось с первых лет установления советской власти. Но при этом старообрядцев заставляли подписывать «декларации» о лояльном отношении к советской власти ${ }^{1}$. Население страдало от малоземелья: в Новозыбковском уезде на 1 хозяйство в среднем приходилось 4,7 десятин земли, наблюдался сплошной недобор хлеба [Еременко 1925: 31-33]. Вследствие малоземелья нужда заставляла крестьян переселяться в другие губернии [Еременко 1925: 63]. Старообрядческое население могло уходить на отхожие промыслы, но своих родных мест не покидало. После революции местное население испытывало тяжести продразверстки. В 1920-х гг. началось обложение сельхозналогом, причем оно предполагало его постепенное увеличение. В 1924-1925 гг. произошло увеличение разряда по налогообложению для Гомельской губернии на 11-12\% по сравнению с предшествующим периодом. Это усиливало негативное отношение старообрядческого населения к органам советской власти на местах. Старообрядцы Злынки (территория Стародубья, но входила в состав Гомельской губернии) тоже не приняли революцию. Здесь сохранялись и действовали старообрядческие храмы и моленные. Духовное окормление общин осуществляли старообрядческие священники и начетчики. Старообрядцы не принимали талоны на получение продуктов от органов советской власти из-за печати, называя ее печатью антихриста. К 1925 г. 90\% населения Злынки составляли старообрядцы. Все старообрядчество с наступлением революции ожидало пришествия антихриста 2 . Аналогичная ситуация была в посаде Климове. Из 6 тыс. населения старообрядцы составляли $92 \% 3$. Органы советской власти постоянно проводили идеологическую работу среди населения. Автор статьи, опубликованной в журнале «Известия Гомельского губернского комитета РКП(б)», Г. Ковалев писал: «Отношение к соввласти и революции еще и сейчас у стариков критическое, а начале революции было еще хуже. Считали, что пришел антихрист и настал конец света. Роль антихриста приписывали Ильичу, но большинство указывало на Троцкого. И еще два года тому назад серьезно ожидали и поговаривали о войне» ${ }^{4}$ В 1920-1930 гг. была разработана программа действий по разрушению традиционного культурнобытового уклада старообрядческого населения. Она включала в себя замену традиций имянаречения по святцам - революционными именами; устранение традиционных религиозных праздников и замену их новыми - социалистическими; ликвидацию икон из мест общественного досуга - школ, клубов, замену их портретами вождей революции, лозунгами. Сделав ставку на молодое поколение, коммунисты вовлекали старообрядческую молодежь в работу школ, кружков, изб-читален, клубов с демонстрацией фильмов. В тех старообрядческих поселениях, где молодежи не было, комитеты по ликвидации безграмотности органы советской власти не предусматривали. Первоначально здания старообрядческих храмов и монастырей после установления советской власти передавались верующим в бесплатное пользование. В 1928-1929 гг. здания у членов старообрядческих общин начали экспроприировать ${ }^{5}$. Наиболее

1 Декларация старообрядцев Левонтевской общины Ветковского района о лояльном отношении к советской власти. - Старообрядиы на Гомельщине (1918-1991)... Документ № 51. C. 67.

2 Бессонов. Старообрядческая Злынка. - Известия Гомельского губкома РКП(б). Цит. по: Старообрядиы на Гомельщине (1918-1991)... Документ № 19. С. 37-39.

3 Старообрядцы на Гомельщине (1918-1991)... Документ № 23. С. 42-45.

4 Там же.

5 ГАБО (Государственный архив Брянской области). Ф. 80. Оп. 1. Д. 1195. Л. 19. 
стойкими последователями старообрядческих традиций оставались женщины. После закрытия храмов и монастырей в своих домах они сохраняли предметы старообрядческого культа. В семьях соблюдались религиозные праздники, детей учили читать «по-церковному». Антирелигиозная направленность деятельности партийных органов проявлялась наиболее жестко в работе на производстве. Так, антирелигиозная кампания на лесозаводе «Социализм» в г. Гомеле провалилась, т.к. рабочие были старообрядцами, а антирелигиозная кампания полностью противоречила духовной составляющей их жизни ${ }^{1}$.

В 1929-1937 гг. старообрядческие поселения Стародубья вошли в состав Западной области РСФСР, а Ветки - в состав Гомельской области БССР в 1938 г. «Поворот на индустриализацию» потребовал значительного увеличения финансирования тяжелой индустрии. Одними из источников финансирования были внутренние резервы промышленных предприятий и расширение возможностей кредитной политики. На это была направлена идеологическая работа партийных и комсомольских органов. Было принято решение вместо праздника Преображения Господня проводить День индустриализации, инициатива проведения которого была выдвинута рабочими Путиловского завода г. Ленинграда. Рабочие клинцовских предприятий должны были поддержать это начинание и отработать 6 августа в фонд индустриализации страны. Однако ряд предприятий Клинцовского округа не откликнулись на это обращение, особенно рабочие фабрики имени Коминтерна. Замена религиозных праздников на «социалистические» означала экономическое, политическое и моральное давление на старообрядческое население. Поэтому старообрядцы стали выбирать пассивную форму сопротивления органам власти и управления на производстве - уклонялись от нововведений.

В период коллективизации старообрядцы не хотели вступать в колхозы. На территории Ветки в деревне Барсуки Осовницкого сельского совета с 1933 г. наблюдалось бегство единоличников из района. «Главным образом уезжают старообрядцы... предварительно разбазаривая свое хоз[яйство]» 2 . Старообрядцы - крепкие хозяева - не желали вступать в колхоз, поэтому распродавали свое имущество, уезжали из традиционных мест проживания. Очень болезненно воспринимался процесс раскулачивания в семьях старообрядцев ${ }^{3}$. Старообрядцы открыто отказывались от вступления в колхоз. В материалах дела о контрреволюционной группе в селе Святске обвиняемая Надежда Сидоровна Сапожникова показывала, что у нее, вдовы, в «период организации колхозов хозяйство и землю отобрали под колхоз. С тех пор я начала заниматься попрошайничеством» 4 . Революция лишила старообрядцев недвижимого имущества, заставила иным образом зарабатывать средства на жизнь. Документы Государственного архива Гомельской области также свидетельствуют о жестких мерах органов советской власти по лишению старообрядцев на территории Ветки избирательных прав. Так, лишенцами были как представители беднейших слоев - крестьяне-хлеборобы, рабочие, так и мелкие собственники, ранее сочувствовавшие большевикам. Так, например, Кушнерев Георгий Ефимович,

\footnotetext{
1 Из протокола № 8 заседания бюро Гомельского горрайкома ВКП(б) о проведении антирелигиозной кампании на заводе «Социализм» от 17 апреля 1923 г. Цит. по: Старообрядцы на Гомельщине (1918-1991)... Документ № 9. С. 30-31.

2 Из специальной сводки № 37 Рогачевского райотдела ГПУ БССР о бегстве старообрядцев из д. Барсуки Осовницкого сельсовета. Цит. по: Старообрядцы на Гомельщине (1918-1991)... Документ № 73. С. 94.

3 Из акта обследования работы Тарасовской школы І ступени Ветковского района от 7 мая 1933 г. Цит. по: Старообрядиы на Гомельщине (1918-1991)... Документ № 58. С. 78.

4 Копии документов были предоставлены авторам старообрядцем - историком и краеведом О.Г. Каменецким, уроженцем с. Свяцка Брянской обл.
} 
58 лет, уроженец слободы Огородня-Гомельская, рабочий-плотник был лишен избирательных прав согласно Конституции СССР в мае 1930 г. ${ }^{1}$; мещанин, торговец Григорий Федорович Павлов был не только лишен избирательных прав, но и выслан за пределы БССР в 1927 г. 2 Зажиточные старообрядцы Стародубья, не желавшие вступать в колхозы, были репрессированы и заключены в концентрационный лагерь под Клинцами. Действительно, слова Н.К. Крупской: «Борьба с кулачеством есть борьба со старообрядчеством» еще раз подтверждают характер репрессивных мер органов советской власти против старообрядцев Стародубья и Ветки. В 1930 г. старообрядческие храмы еще были полны верующих, процент посещающих храмы увеличивался. При этом проявления действий антисоветского характера не были отмечены ${ }^{3}$. Старообрядцы Ветки не пускали своих детей в дни религиозных праздников в школу ${ }^{4}$. В 1928-1929 гг. при переводе обучения в школах Белоруссии на белорусский язык старообрядцы отстояли право обучения своих детей на русском языке.

1932-1936 гг. стали тяжелым периодом в истории старообрядческих поселений. Это время связывают с голодом. Самым тяжелым был 1933 г. Голод был вызван перегибами в политике коллективизации. В своих мемуарах «Мои Клинцы» П.М. Храмченко отмечал, что голод в Клинцах был сильный. К.И. Потапов, житель деревни Марьино, в своем опросном листе свидетельствовал о голоде, отходных промыслах и тяжелом социальном положении старообрядцев в 1930-х гг. «В 1933 г. во время голода люди собирали листья липы, «лепили из них кучу на воде и ели. Часто умершие лежали на улицах, пока кто-нибудь из односельчан их не закапывал без всякого обряда погребения. Распространялся тиф, дизентерия» 5 . В 1933-1934 гг. началось массовое закрытие старообрядческих храмов. Это больно ударило по сплоченности старообрядческих общин. В старообрядческих храмах органы советской власти создавали склады зерна и стройматериалов. Старообрядцы вновь тайно стали молиться по домам. Традиционная народная религиозность, характерная для старообрядцев, с особенной силой проявится позже, в период Великой Отечественной войны, когда произошло возрождение старообрядческих общин,

Итак, в результате проведенного нами исследования мы пришли к следующим выводам.

Старообрядцы проявили стойкое сопротивление насильственному изменению традиционного культурно-бытового уклада после Октября 1917 г. Оно по своей форме было как активным, так и пассивным. Они открыто не признавали революцию и считали, что настал «конец света и к власти пришел антихрист» (В.И. Ленин, Л.Д. Троцкий), считали, что в ближайшее время начнется война. Крестьянское население после революции страдало от малоземелья. Активная форма стойкого сопротивления проявлялась в отсутствии добровольного вхождения в колхозы в 1930-е гг., отъезде крестьян-единоличников из родных мест в период коллективизации, отказе от получения продуктов по талонам из-за

\footnotetext{
1 Старообрядцы на Гомельщине (1918-1991)... Документ № 59. С. 79-80.

2 Старообрядиы на Гомельщине (1918-1991)... Документ № 60. С. 80-81.

3 Специальная сводка № 36 Гомельского окружного отдела ГПУ БССР «Об отмеченных недочетах в общественных организациях в проведении антирелигиозной кампании и отражении пасхальных дней в рабочей среде от 21 апреля 1930 г. - Старообрядцы на Гомельщине (19181991)... Документ № 57. С. 75-77.

4 Из-за праздников некогда учиться. - Полесская правда. 23 апреля 1927 г. Цит. по: Старообрядиы на Гомельщине (1918-1991)... Документ № 30. С. 49.

5 Из опросного листа К.И. Потапова, жителя д. Марьино Добрушского района, о занятиях старообрядцев, тяжелом социальном положении в начале 1930-х гг. - Старообрядиы на Гомельщине (1918-1991)... Приложение. С. 295.
} 
наличия на них «антихристовой печати», отказе посылать детей на обучение в белорусские школы. Старообрядцев заставляли подписывать декларации о лояльном отношении к советской власти, изымали у старообрядческих общин здания храмов и монастырей. Пассивная форма сопротивления была связана с неприятием антирелигиозной пропаганды, новых социалистических праздников. Антирелигиозная кампания на производстве и в общественной жизни полностью противоречили духовной составляющей жизни старообрядцев. Старообрядцы запрещали своим детям посещать советские школы в период религиозных праздников. Но старообрядцы не осуществляли действия антисоветского характера. Насильственное введение празднования Дня индустриализации органами советской власти предполагало изъятие финансовых средств у населения, приводило к физическому перенапряжению, политическому и моральному давлению. В 1932-1933 гг. значительная часть старообрядческого населения умерли от голода. Старообрядцы стойко противостояли этим мерам государства, сохраняя при этом свои обряды и традиции. Это проявилось в сохранении народной религиозности и привело в будущем к возрождению старообрядческих общин.

\section{Список литературы}

Еременко П. 1925. Новозыбковский уезд: пособие для школ, изб-читален, кружков самообразования и др. Новозыбков: Новозыбковское уездное бюро краеведения. $110 \mathrm{c}$.

Кочергина М.В. 2011. Стародубье и Ветка в истории русского старообрядчества (1760-1920 гг.): демографическое развитие старообрядческих общин, предпринимательство, духовная жмизнь, культура. Брянск: ООО «Ладомир». $451 \mathrm{c.}$

Фирсов С.Л. 2002. Русская иерковь накануне перемен (конеи, 1890-1918 г.). М.: Типография ППП «Наука». 623 с.

DZYUBAN Valeriy Valer'evich, Dr.Sci. (Hist.), Cand.Sci. (Ped.), Professor of the Department of Sociology, History and Philosophy, Financial University under the Government of the Russian Federation (49 Leningradsky Ave, Moscow, GSP-3, Russia, 125993; bryanskstudzuban@mail.ru)

KOCHERGINA Marina Viktorovna, Cand.Sci. (Hist.), Associate Professor of Moscow Financial and Law University (bld. 1, 17 Serpukhovsky Val St, Moscow, Russia, 115191; kochergina_mv@mail.ru)

\section{PERSISTENT RESISTANCE OF OLD BELIEVERS OF STARODUB'YE AND VETKA TO VIOLENT CHANGE BY THE ORGANS OF SOVIET POWER OF THE TRADITIONAL CULTURAL AND EVERYDAY LIFE OF THE POPULATION (1920s-1930s)}

\footnotetext{
Abstract. The article is devoted to the actual problem of preservation of traditional cultural and everyday life of the Russian old believers of the ancient spiritual centers of Starodub'ye and Vetka in the period of 1920-1930, despite the ideological influence and repressions by the Soviet authorities. Researchers in other regions of compact residence of old believers, for example, in the Urals, Siberia, Eastern Europe, also pay attention to this problem. The topic developed by the authors has not been previously studied by both domestic and foreign scientists. In part, the authors published some aspects of this problem earlier.
}

Keywords: old believers, Starodub'ye, Vetka, collectivization, industrialization, spiritual centers, ideological influence, repressions 